\title{
Pengaruh Non-linear Kompensasi Manajemen dan Aspek Keahlian Dewan Komisaris Terhadap Penghindaran Pajak
}

\author{
Gandy Wahyu Maulana Zulma* \\ Fakultas Ekonomi dan Bisnis, Universitas Jambi, 36363, Jambi, Indonesia \\ *Correspondence email: maulanagandi25@unja.ac.id
}

\begin{abstract}
Abstrak. Penelitian ini berfokus pada pengaruh non-linear dari kompensasi manajemen serta aspek keahlian dewan komisaris terhadap penghindaran pajak perusahaan. Penelitian ini memanfaatkan data sekunder yang diperoleh dari Bursa Efek Indonesia dengan sampel berupa industry manufaktur yang memenuhi kriteria. Berdasarkan hasil seleksi sampel diperoleh sebanyak 345 sampel observasi dari tiga tahun pengamatan (2017 hingga 2019). Teknik analisis penelitian ini menggunakan regresi, uniknya dalam penelitian ini pada variabel kompensasi manajemen yang diuji secara khusus dalam bentuk kuadratik untuk menguji pengaruh non-linear kompensasi manajemen terhadap penghindaran pajak. Hasil penelitian ini menunjukkan bahwa terdapat pengaruh non-linear antara kompensasi manajemen dan penghindaran pajak. Selain itu, aspek keahlian sangat penting untuk dimiliki oleh dewan komisaris dalam menjalankan fungsi pengawasannya. Dengan adanya keahlian dewan komisaris dapat mendorong keputusan manajemen yang lebih cenderung konservatif. Hasil temuan ini dapat berkontribusi dalam pengembangan bidang perpajakan dan tatakelola perusahaan yang memberikan arah baru untuk melengkapi temuan penelitian sebelumnya khususnya terkait hubungan non-linear antara kompensasi manajemen dan penghindaran pajak perusahaan.
\end{abstract}

Kata kunci: Dewan Komisaris; Kompensasi Manajemen; Penghindaran pajak

\begin{abstract}
This study focuses on the non-linear effect of management compensation and the expertise of the board of commissioners on corporate tax avoidance. This study utilizes secondary data obtained from the Indonesia Stock Exchange with a sample in a manufacturing industry that meets the criteria. Based on the results of sample selection, 345 observation samples were obtained from three years of observation (2017 to 2019). The analysis technique of this study uses regression, and uniquely in this study, the management compensation variable was specifically tested in the quadratic form to test the non-linear effect of management compensation on tax avoidance. The results of this study indicate that there is a non-linear effect between management compensation and tax avoidance. In addition, the aspect of expertise is very important for the board of commissioners to carry out its supervisory function. The expertise of the board of commissioners can encourage management decisions that tend to be more conservative. These findings can contribute to the development of taxation and corporate governance, which provides a new direction to complement previous research findings, especially regarding the non-linear relationship between management compensation and corporate tax avoidance.
\end{abstract}

Keywords: Board of Commissioners; Management Compensation; Tax Avoidance

\section{PENDAHULUAN}

Beberapa waktu belakangan ini kasus penghindaran pajak perusahaan di Indonesia semakin meningkat. Pada tahun 2020, Tax Justice Network melaporkan bahwa perkiraan kerugian negara akibat penghindaran pajak yang mencapai 4,8 miliar dolar amerika serikat per tahun atau setara dengan 68,7 triliun apabila dikonversi dengan mata uang rupiah saat itu. Sebagian besar kerugian yang ditanggung negara, berasal dari penghindaran pajak yang dilakukan oleh perusahaan-perusahaan di Indonesia (Yusuf, I.S., 2020). Hal ini sangat memprihatinkan dan menjadi permasalahan yang masih perlu dibenahi oleh negara hingga saat ini. Namun, disatu sisi tidak dapat dipungkiri bahwa beban pajak merupakan salah satu faktor yang dapat menurunkan keuntungan yang diperoleh oleh perusahaan, sehingga tidak jarang banyak perusahaan yang mencoba mengambil keuntungan dari penghematan pajak.

Evaluasi kinerja sering kali dikaitkan dengan berapa besaran kompensasi yang akan diberikan kepada manajemen perusahaan. Beberapa penelitian terdahulu yang membahas mengenai topik kompensasi manajemen seringkali dihubungkan dengan teori keagenan. Dalam perspektif teori keagenan terdapat kepentingan antara pemilik (principal) dan manajemen perusahaan (agen). Dimana pemilik mengharapkan keuntungan maupun memaksimalkan nilai perusahaan sementara manajemen mengharapkan kesejahteraan baik dari gaji maupun bonus atas kinerja yang telah mereka hasilkan. Oleh karena itu, kompensasi merupakan nilai jasa yang diberikan oleh pemilik perusahaan kepada manajemen (Jensen \& Murphy, 1990). Sebagian besar skema kompensasi didasarkan evaluasi dari kinerja manajemen yaitu pencapaian dalam meningkatkan laba bersih dan harga saham (Scott, 2009; Vovchenko et al., 2016).

Dalam praktiknya, sering kali terjadi konflik kepentingan antara pemilik dan manajemen yang menjalankan perusahaan. Adapun upaya untuk meminimalkan atau mengendalikan konflik yang terjadi antara manajemen perusahaan dengan pemilik dapat ditawarkan melalui sistem kompensasi manajemen yang 
tepat. Burchman \& Jones (2006) menyatakan bahwa penerapan sistem kompensasi yang tepat diharapkan mampu menarik dan mempertahankan manajer yang kompeten dengan mengaitkan keputusan untuk memaksimalkan nilai perusahaan. Hal ini didasari oleh pemikiran bahwa kompensasi manajemen yang ditetapkan dengan baik dapat mendorong pertumbuhan kinerja perusahaan, sehingga dapat memaksimalkan nilai perusahaan.

Cukup banyak penelitian sebelumnya dibidang perpajakan yang mencoba untuk menjelaskan pengaruh dari insentif kompensasi yang diberikan kepada manajemen terhadap praktik penghematan pajak yang secara konsisten mengasumsikan bahwa kompensasi manajemen dapat membantu menyelaraskan kepentingan antara manajemen dengan pemegang saham (Desai, M. \& D. Dharmapala, 2006; Minnick \& Noga, 2010; Rego, S. O., \& Wilson, R., 2012; Armstrong, et al., 2012). Namun Sebagian besar penelitian sebelumnya tidak mempertimbangkan aspek motivasi yang berlebihan dari manajer untuk memaksimalkan besaran kompensasi, kemungkinan dapat menimbulkan risiko besar bagi reputasi perusahaan. Contohnya motivasi semula untuk sekedar menghemat pajak dapat berujung pada praktik penghindaran pajak secara agresif yang bertentangan dengan peraturan dan berisiko melanggar hukum yang berlaku. Karena manajer membuat keputusan berdasarkan toleransi risiko pribadinya yang mungkin lebih rendah daripada pemegang saham lainnya. Manajemen perusahaan mungkin saja dapat mengambil risiko yang tidak memadai jika dibandingkan dengan perspektif pemegang saham (Low, 2009).

Tidak semua perusahaan mendukung dan berani mengambil risiko dalam menghindari pajak. Graham, J. $\mathrm{R}$, et al (2014) menyatakan bahwa perusahaan publik maupun perusahaan besar biasanya lebih peduli tentang konsekuensi reputasi yang merugikan dari penghindaran pajak. Hal ini sangat masuk akal, karena semakin besar ukuran perusahaan maka akan semakin menjadi pusat perhatian dan banyak pihak yang berkepentingan terhadap setiap aktivitas yang dilakukan oleh perusahaan itu. Sementara sebaliknya, perusahaan dengan ukuran relative lebih kecil cenderung di luar perhatian khusus yang membuat mereka lebih leluasa dalam menghindari pajak sehingga cenderung untuk melakukan praktik penghindaran pajak yang agresif. Oleh karena itu, penelitian ini mencoba menjelaskan bagaimana skema kompensasi dapat memiliki pengaruh ganda yang dapat dilihat dari dua sisi.

Di satu sisi, insentif kompensasi yang diberikan dapat mendorong manajemen untuk terlibat dalam aktivitas penghindaran pajak yang menghasilkan laba dan peningkatan nilai perusahaan. Di sisi lain, insentif kompensasi dapat mengurangi Tindakan oportunis manajemen dalam melakukan penghindaran pajak perusahaan untuk mencegah keputusan penghindaran pajak yang berisiko bagi reputasi perusahaan. Dengan adanya dua sisi berbeda ini diharapkan dapat membantu menjelaskan dengan lebih baik secara teoritis mengapa penelitian sebelumnya menemukan bukti yang beragam tentang hubungan antara kompensasi manajemen dan penghindaran pajak. Selain itu, terdapat faktor penting selain kompensasi manajemen yang dapat mempengaruhi keputusan penghindaran pajak perusahaan. Beberapa penelitian telah mengeksplorasi dampak dari karakteristik pribadi dewan direksi maupun komisaris pada keputusan bisnis perusahaan $(\mathrm{Ge}, \mathrm{W}$. et al., 2011). Ge, W., et al (2011) menemukan bahwa terapadat faktor karakteristik individu, seperti jenis kelamin, usia dan latar belakang Pendidikan yang dapat berpengaruh pada kinerja keuangan perusahaan. Temuan penelitian sebelumnya menunjukkan bahwa pengalaman kerja dan karakteristik pribadi dari manajemen kunci perusahaan memiliki dampak yang besar pada berbagai keputusan dan kinerja operasional perusahaan.

Tidak dapat dipungkiri bahwa perkembangan perpajakan internasional dan standar akuntansi terus bergerak sangat pesat, sehingga menimbulkan praktik bisnis yang sangat kompleks dan membutuhkan tingkat keahlian yang tinggi dari dewan komisaris perusahaan untuk mengawasi aktivitas perusahaan. Tidak hanya masalah domestik, perusahaan di era saat ini juga menghadapi masalah kepatuhan pajak internasional yang semakin kompleks. Misalnya, rencana aksi base erosion and profit shifting (BEPS) mensyaratkan pembagian keuntungan di antara transaksi harga transfer perusahaan agar sesuai dengan substansi ekonomi dari transaksi tersebut, yang seringkali memerlukan analisis laporan keuangan pihak berelasi. Sehingga apabila tingkat keahlian dewan komisaris yang kurang memadai tentunya akan berdampak terhadap efektivitias pengawasan sehingga tidak mampu untuk mendeteksi mana keputusan manajemen yang dapat memaksimalkan nilai perusahaan dan keputusan yang berisiko bagi reputasi perusahaan.

Chen, M. C., et al (2020) menyatakan bahwa tingkat keahlian akuntansi yang dimiliki oleh dewan komisaris tentunya dapat membantu dalam mempersiapkan analisis keuangan untuk tujuan perpajakan. Selain itu, baik peraturan perpajakan maupun standar akuntansi dalam perkembangannya terus menuntut transparansi yang lebih tinggi atas transaksi bisnis yang dilakukan perusahaan serta informasi pajak yang dilaporkan. Sehingga, dalam menentukan proporsi jajaran manajemen kunci perusahaan hendaknya perlu mempertimbangkan latarbelakang keahlian ini karena mungkin memiliki keuntungan dalam menangani perencanaan pajak dengan tingkat pengawasan yang lebih baik apabila dibandingkan dengan dewan komisaris tanpa keahlian di bidang akuntansi.

Berdasarkan tinjauan literatur di atas, penelitian ini dapat memberikan beberapa kontribusi penting dalam pengembagan kajian teori maupun praktis di bidang 
perpajakan. Pertama, penelitian ini berkontribusi untuk penelitian terbaru yang berfokus pada kompensasi dengan mempertimbangkan efek non-linear dari kompensasi manajemen terhadap keputusan penghindaran pajak perusahaan. Kedua, Penelitian dapat menjelaskan secara khusus mengenai aspek keahlian akuntansi yang belum pernah dikaji secara khusus pada penelitian sebelumnya yang dinilai dapat meningkatkan efektivitas dewan komisaris dalam menjalankan fungsi pengawasan terhadap aktivitas penghindaran pajak yang dinilai dapat menguntungkan atau justru berisiko bagi reputasi perusahaan.

\section{METODE \\ Model Penelitian}

Beberapa penelitian terdahulu telah mencoba menjelaskan pengaruh antara kompensasi manajemen terhadap penghindaran pajak, hasilnya sejauh ini masih tidak konsisten (Armstrong, et al., 2015). Hanlon, M., et al (2005) menemukan bahwa skema pemberian kompensasi dapat mengarah kepada praktik penghindaran pajak yang lebih agresif. Minnick \& Noga (2010) menemukan bahwa kompensasi manajemen yang tinggi dapat meredakan konflik keagenan dan mendorong manajer untuk memilih strategi penghematan pajak yang dapat meningkatan nilai jangka panjang perusahaan. Sehingga dapat disimpulkan bahwa kedua penelitian di atas sepakat bahwa kompensasi manajemen berpengaruh positif terhadap tingkat penghindaran pajak perusahaan.

Disisi lain, Desai, M. \& D. Dharmapala (2006) menemukan pengaruh negative antara kompensasi manajemen dan tingkat penghindaran pajak perusahaan. Ketika tingkat kompensasi manajemen menjadi lebih tinggi, kepentingan manajemen lebih selaras dengan pemegang saham yang membatasi tindakan opotunis manajemen sehingga tingkat penghindaran pajaknya menjadi lebih rendah. Zulma, G.W.M (2016) juga menemukan pengaruh negative antara kompensasi manajemen dan penghindaran pajak perusahaan dimana tindakan oportunis manajemen dalam melakukan penghindaran pajak dinilai dapat menimbulkan risiko bagi reputasi perusahaan. Selain itu, Armstrong, et.al (2012) justru tidak menemukan hubungan keduanya antara kompensasi manajemen dan penghindaran pajak seperti yang ditemukan oleh penelitian lainnya. Berdasarkan inkonsistensi hasil dalam konteks penelitian yang telah dilakukan, maka dapat diduga bahwa terdapat efek non-linear antara kompensasi manajemen dan penghindaran pajak, sehingga hipotesis pertama dalam penelitian ini yaitu:

$\mathrm{H}_{1} \quad$ : Adanya pengaruh non-linear antara kompensasi manajemen terhadap penghindaran pajak perusahaan

Selain itu, perlu adanya fungsi pengawasan yang baik dalam struktur perusahaan untuk memastikan bahwa manajemen membuat keputusan pajak yang efisien. Tetapi ketika struktur pengambilan keputusan perusahaan dibangun karena ukuran dewan direksi yang besar dan adanya berbagai perspektif, dan mungkin dengan berbagai motif seperti mengejar kepentingan, politik, partai dan lain-lain tentu akan membuat keputusan yang diambil dapat bias dan berisiko bagi perusahaan (Hoseini, M. et al., 2019). Hal ini menunjukkan bahwa perlu perhatian khusus dalam menentukan komposisi dari dewan komisaris sebagai fungsi pengawasan yang menjadi perwakilan pemegang saham dalam mengawasi kinerja manajemen perusahaan. Dewan komisaris harus mampu mendeteksi dan mencegah setiap keputusan yang dapat merugikan perusahaan khususnya dalam hal pengambilan keputusan penghindaran pajak yang dapat berisiko bagi reputasi perusahaan.

Oleh karena itu, penting bagi seorang dewan komisaris untuk memiliki keahlian khususnya dalam bidang akuntansi dan perpajakan untuk dapat mencegah praktik penghindaran pajak yang berisiko bagi reputasi perusahaan. Chen, M. C. et al (2020) menemukan bahwa faktor kompetensi pada manajemen kunci berhubungan negative dengan penghindaran pajak perusahaan. Temuan ini menunjukkan bahwa aspek kompetensi dan keahlian akuntansi memiliki pengaruh yang nyata terhadap tingkat penghindaran pajak perusahaan. Jiang, F., et al. (2013) menemukan bahwa CEO dengan keahlian keuangan dikaitkan dengan pelaporan laba yang lebih konservatif dan kualitas laba yang lebih tinggi. CEO dengan keahlian akuntansi mungkin memiliki pengaruh yang lebih besar dalam mengarahkan keputusan pelaporan pajak perusahaan daripada rekan mereka yang tidak memiliki keahlian akuntansi. Penghindaran pajak mungkin dapat memberikan tambahan ekonomis bagi perusahaan, namun tentunya dapat berisiko pula bagi perusahaan di masa depan. Sehingga penting bagi dewan komisaris untuk dapat mendeteksi potensi penghindaran pajak yang dapat merugikan perusahaan.

$\mathrm{H}_{2}$ : Keahlian Dewan Komisaris dapat berpengaruh negative terhadap penghindaran pajak

Adapun model untuk menguji hipotesis dalam penelitian ini yaitu:

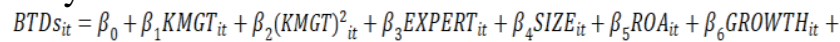
$\beta_{7} I N V I N T_{i t}+\beta_{8} C I N T_{i t}+\beta_{9} L E V_{i t}+\epsilon_{\text {it }}$

Keterangan:

$B T D s_{i t} \quad=$ Penghindaran pajak perusahaan $i$ pada tahun $t$

$K M G T_{i t} \quad=$ Logaritma natural dari nilai kompensasi manajemen kunci perusahaan $i$ pada tahun $t$

$E X P E R T_{i t}=$ Indeks skor dari butir pernyataan keahlian dewan komisaris perusahaan $i$ pada tahun $t$ SIZE $_{i t}=$ Logaritma natural total asset perusahaan $i$ pada tahun $t$ 
$R O A_{i t}=$ Laba bersih dibagi total asset perusahaan $i$ pada tahun $t$

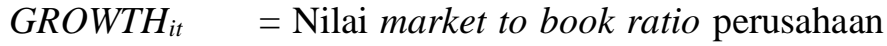
$i$ pada tahun $t$

$I_{N V I N T_{i t}}=$ Total persediaan dibagi total asset perusahaan $i$ pada tahun $t$

CINT $_{\text {it }}=$ Total asset tetap dibagi total asset perusahaan $i$ pada tahun $t$

$L E V_{i t} \quad=$ Total liabilitas dibagi total ekuitas perusahaan $i$ pada tahun $t$

\section{Sampel Penelitian}

Penelitian ini menggunakan jenis data crosssection. Proses pemilihan sampel menggunakan metode purposive sampling. Penelitian ini berfokus pada laporan keuangan perusahaan manufaktur periode 2017-2019. Alasan pembatasan data hingga tahun 2019 untuk mengurangi efek bias dari dampak pandemi yang dimulai pada tahun 2020 hingga sekarang yang berdampak pada pembayaran pajak perusahaan sehingga dikhawatirkan dapat mempengaruhi hasil penelitian. Berdasarkan beberapa kriteria yang digunakan untuk mendapatkan sampel yang representative dengan tujuan penelitian, maka diperoleh sebanyak 345 sampel observasi tahun-perusahaan yang sesuai dengan kriteria seperti tidak mengalami delisting selama periode pengamatan, memiliki data yang lengkap sesuai kebutuhan penelitian serta menggunakan mata uang rupiah sebagai standar untuk memastikan konsistensi nilai yang terkandung dalam data penelitian yang diolah. Selain itu, penelitian ini menggunakan persamaan regresi (ordinary least square) untuk menguji hipotesis penelitian dengan dibantu alat olah data yang bernama eviews.

Tabel 1. Sampel

\begin{tabular}{lcc}
\hline & $\begin{array}{c}\text { Tahun } \\
\text { Perusahaan }\end{array}$ & $\begin{array}{c}\text { Jumlah } \\
\text { Perusahaan }\end{array}$ \\
\hline Manufaktur Per Maret 2020 & 420 & 140 \\
Dikurangi: & & \\
Delisting selama periode 2017-2019 & $(36)$ & $(12)$ \\
Data tidak lengkap & $(24)$ & $(8)$ \\
Menggunakan Mata Uang Asing & $(15)$ & $(5)$ \\
Total Sampel Observasi & $\mathbf{3 4 5}$ & $\mathbf{1 1 5}$ \\
\hline
\end{tabular}

Sumber: Data Diolah

\section{Operasionalisasi Variabel}

Pengukuran variabel dependen yaitu penghindaran pajak menggunakan book tax differences (BTDs) yang mengacu pada penelitian Tang, T., \& Firth, M. (2011).

\footnotetext{
BTDs $=$ Book Income - Taxable Income $/$ Total Asset Keterangan :

BTDs = Beda Laba Fiskal dan Komersial

Book Income $=$ Laba Sebelum Pajak

Total Asset $=$ Total dari aset yang dimiliki oleh perusahaan
}

Variabel independen utama pada penelitian ini adalah kompensasi manajemen dan keahlian dewan komisaris. Variabel independent utama yang pertama yaitu kompensasi manajemen dinilai berdasarkan logaritma natural dari jumlah kompensasi yang diterima manajemen kunci baik oleh dewan direksi maupun dewan komisaris perusahaan yang datanya dikumpulkan secara hand-collected dari catatan atas laporan keuangan yang mengacu pada penelitian Armstrong, et.al (2012). Untuk menguji hipotesis pertama penelitian, khusus untuk variabel kompensasi manajemen dirubah kedalam bentuk kuadratik (bilangan berpangkat dua) untuk menguji hubungan non-linear antara kompensasi manajemen dengan penghindaran pajak.

Selain itu, variabel independent yang kedua yaitu keahlian dewan komisaris diukur berdasarkan indeks skor dengan kriteria pernyataan yang adopsi dari Indonesian Institute for Corporate Directorship (IICD) yang dimodifikasi sesuai kebutuhan penelitian untuk dapat megukur dengan baik tingkat keahlian yang dimiliki oleh dewan komisaris masing-masing perusahaan. Dengan beberapa kriteria yang dipertimbangkan seperti latar belakang Pendidikan, kematangan usia, serta pengalaman. Kemudian setiap butir pernyataan diceklis dengan pembobotan 1-3 dimana 1 artinya "poor", 2 artinya "fair", dan 3 artinya "good". Kemudian nilia ini dikonversi dengan rumus sebagai berikut:

\section{EXPERT $=$ Score $/$ Total Score}

Keterangan :

Expert $=$ Indeks skor tingkat keahlian dewan komisaris

Score $=$ Bobot dari ceklis butir pernyataan kriteria yang diukur.

Total Score = Nilai keseluruhan dari sekumpulan butir pernyataan

\section{HASIL DAN PEMBAHASAN \\ Pengujian Hipotesis}

Sebelum malakukan pengujian hipotesis, telah dipastikan terlebih dahulu bahwa persamaan regresi telah memenuhi syarat statistik yang terbebas dari permasalahan autokorelasi maupun heteroskedastisitas. Dalam penelitian ini telah dilakukan treatment dengan mengontrol standar error untuk menghilangkan permasalahan terjadinya varians yang tidak konstan dan terjadi otokorelasi dalam errornya. Berdasarkan hasil pengujian statistic diperoleh nilai Durbin Watson dari model yang berada disekitar angka 2 yang mengindikasikan bahwa hasil regresi pada persamaan yang digunakan dalam penelitian ini telah terbebas dari permasalahan autokorelasi.

Berdasarkan hasil uji chow dan uji hausman yang dilakukan, persamaan regeresi yang fit dengan data penelitian ini yaitu menggunakan Random Effect Model. Tabel 2 menjukkan statistic deskriptif dari masing- 
Gandy Wahyu Maulana Zulma, Pengaruh Non-linear Kompensasi Manajemen dan Aspek Keahlian Dewan Komisaris Terhadap Penghindaran Pajak

masing variabel dimana nilai logaritma natural kompensasi manajemen memiliki rata-rata sebesar 23.15 dengan nilai maksimum 142,12 dan minimum 20,04. Hal ini menunjukkan bahwa besaran kompensasi yang tersebar dalam sampel perusahaan penelitian ini cukup bervariasi. Hal ini mungkin dipengaruhi oleh perbedaan ukuran perusahaan (SIZE) dan kinerja perusahaan (ROA) yang berbeda-beda pada tahun pengamatan sampel sehingga berbeda pula tingkat kompensasi manajemen yang dibayarkan oleh masing-masing perusahaan.

Tabel 2. Statististik Deskriptif

\begin{tabular}{lrrrrrr}
\hline \hline Statistik Deskriptif & & & & & & \\
\hline & N & Mean & Median & Maksimum & Minimum & Std.Dev \\
\cline { 2 - 7 } BIDs & 345 & 0,02 & 0,02 & 0,04 & 0,00 & 0,06 \\
KMGT & 345 & 23,15 & 30,94 & 142,12 & 20,04 & 25,14 \\
EXPERT & 345 & 0,65 & 0,67 & 0,92 & 0,42 & 0,68 \\
& & & & & & \\
Variabel Kontrol & & & & & & \\
SIZE & 345 & 5,92 & 1,21 & 212,05 & 9,42 & 18,61 \\
ROA & 345 & 8,25 & 6,23 & 68,75 & $-45,94$ & 11,53 \\
GROWTH & 345 & 2,96 & 1,07 & 235,32 & $-93,4$ & 15,2 \\
INVINT & 345 & 0,27 & 0,24 & 0,73 & 0,02 & 0,12 \\
CINT & 345 & 0,35 & 0,42 & 0,91 & 0,03 & 0,24 \\
LEV & 345 & 1,66 & 0,93 & 120,34 & $-84,44$ & 12,12 \\
\hline
\end{tabular}

Keterangan Variabel:

$B T D_{s_{i t}}=$ Beda laba fiskal dan komersial, $K M G T_{i=}=$ logaritma natural nilai Kompensasi yang diterima oleh manajemen kunci perusahaan, EXPERTi= Indeks skor keahlian dewan komisaris, $S I Z E_{i=}=$ Logaritma natural total asset, $R O A_{i}=$ laba bersih dibagi dengan total asset, Growthi= nilai dari market to book ratio, INVINTi= total persediaan dibagi dengan total asset, $C I N T_{i t}=$ Total asset tetap dibagi dengan total asset, dan $L E V_{i=}=$ total liabilitas dibagi dengan total ekuitas.

Kolom (1) dan (2) dari Tabel 3 menyajikan analisis regresi pengujian hipotesis. Kolom (1) menunjukkan hasil regresi tanpa (KMGT) $)^{2}$, dengan asumsi adanya hubungan linier antara kompensasi manajemen dengan penghindaran pajak. Hasilnya menunjukkan bahwa koefisien pada variabel KMGT memiliki tanda positif, yang menunjukkan adanya hubungan tetapi tidak signifikan secara statistik. Sedangkan, Kolom (2) menunjukkan bahwa ketika variabel $(\mathrm{KMGT})^{2}$ dimasukkan kedalam persamaan model regresi, hasilnya menunjukkan bahwa variabel KMGT dan (KMGT) ${ }^{2}$ menjadi signifikan pada tingkat signifikansi $1 \%$ dengan koefisien arah positif dan negatif. Hasil ini menunjukkan bahwa terdapat pengaruh non-linear antara kompensasi manajemen dengan penghindaran pajak, sehingga hipotesis 1 diterima. Selain itu, variabel EXPERT secara konsisten baik pada Kolom (1) maupun Kolom (2) terbukti signifikan pada level 1\% dengan koefisien arah negative sesuai dengan prediksi arah, sehingga dapat dikatakan bahwa hipotesis 2 juga diterima.
Tabel 3. Hasil Regresi

\begin{tabular}{|c|c|c|c|}
\hline & & (1) & (2) \\
\hline Variabel Bebas & Prediksi Arah & $B T D s$ & $B T D s$ \\
\hline$K M G T$ & $+/-$ & $\begin{array}{c}0,00 \\
(0,58)\end{array}$ & $\begin{array}{c}0,04^{* * *} \\
(2,64)\end{array}$ \\
\hline$(K M G T)^{2}$ & $+/-$ & & $\begin{array}{c}-0,01^{* * *} \\
(-2,62)\end{array}$ \\
\hline EXPERT & - & $\begin{array}{c}-0,91^{* 8 *} * \\
(-2,63)\end{array}$ & $\begin{array}{c}-0,73 * * * \\
(-2,26)\end{array}$ \\
\hline \multicolumn{4}{|l|}{ Variabel Kontrol } \\
\hline SIZE & - & $\begin{array}{c}-0,01^{* * *} * \\
(2,93)\end{array}$ & $\begin{array}{c}-0,01 * * * \\
(2,90)\end{array}$ \\
\hline GROWTH & - & $\begin{array}{c}0,02 \\
(2,06)^{* *}\end{array}$ & $\begin{array}{c}0,02 \\
(2,06)^{* *}\end{array}$ \\
\hline INVINT & + & $\begin{array}{c}0,07 \\
(1,58)\end{array}$ & $\begin{array}{c}0,07 \\
(1,58)\end{array}$ \\
\hline$C I N T$ & - & $\begin{array}{l}-0,01 \\
(-0,07)\end{array}$ & $\begin{array}{c}-0,01 \\
(-0,07)\end{array}$ \\
\hline$R O A$ & + & $\begin{array}{c}0,01^{* * *} \\
(9,08)\end{array}$ & $\begin{array}{c}0,01 * * * \\
(9,08)\end{array}$ \\
\hline$L E V$ & + & $\begin{array}{l}0,01^{*} \\
(1,81)\end{array}$ & $\begin{array}{l}0,01^{*} \\
(1,81)\end{array}$ \\
\hline R-squared & & 0,25 & 0,27 \\
\hline Adjusted R-squared & & 0,24 & 0,25 \\
\hline \# Observasi & & 345 & 345 \\
\hline \# Emiten Manufaktur & & 115 & 115 \\
\hline \multicolumn{4}{|c|}{ 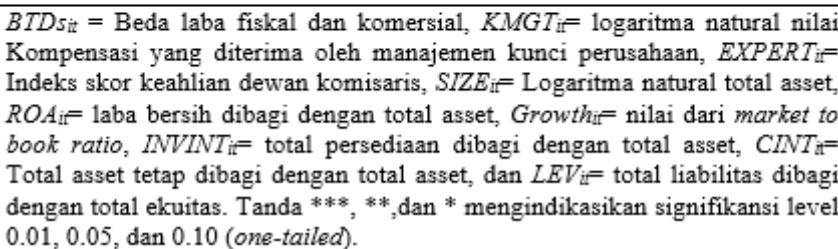 } \\
\hline
\end{tabular}

Beberapa variabel kontrol dalam persamaan model regresi penelitian ini juga terbukti dapat mempengaruhi penghindaran pajak perusahaan. Variabel SIZE signifikan pada level 1\% dengan koefisien arah positif sesuai dengan prediksi arah yang menunjukkan bahwa semakin besar ukuran perusahaan, maka semakin rendah tingkat penghindaran pajaknya. Variabel GROWTH juga terbukti signifikan pada level 5\% dengan arah koefisien positif. Artinya semakin tinggi tingkat pertumbuhan perusahaan maka semakin tinggi pula tingkat penghindaran pajaknya. Variabel ROA terbukti signifikan pada level $1 \%$ dengan koefisien arah positif, dan variabel LEV juga signifikan pada tingkat signifikansi cukup rendah yaitu $10 \%$ dengan koefisien arah positif.

\section{Pembahasan}

Hasil penelitian ini menemukan bahwa terdapat pengaruh non-linear antara kompensasi manajemen dengan penghindaran pajak. Artinya pada batas tertentu kompensasi yang diberikan dapat meningkatkan penghindaran pajak perusahaan, namun kemudian nilainya menurun seperti efek parabola, Ketika mencapai nilai puncak maka selanjutnya akan terjadi penurunan. Dengan kata lain, pada kondisi besaran kompensasi yang diberikan lebih rendah kepada manajemen perusahaan, maka ada hubungan positif antara kompensasi manajemen dan penghindaran pajak perusahaan karena diduga ada motivasi manajemen untuk melakukan penghematan pajak untuk menunjang kinerja keuangan yang mungkin dapat menambah bonus tahunan mereka 
(Hanlon, M., et al., 2005; Minnick, K., \& Noga, T., 2010). Namun, pada kondisi besaran kompensasi manajemen yang lebih tinggi, ada hubungan negatif antara kompensasi manajemen dan penghindaran pajak perusahaan (Desai, M. \& D. Dharmapala., 2006; Zulma, G.W.M., 2016). Karena masalah pertimbangan risiko yang membuat manajemen lebih konservatif dalam mengambil keputusan penghindaran pajak untuk menghindari rusaknya reputasi perusahaan dan kemungkinan pelanggaran hukum yang dapat menimbulkan sanksi maupun denda serta reaksi pasar maupun stakeholder terhadap keputusan berisiko yang diambil oleh manajemen.

Dalam survey yang dilakukan pada penelitian Graham, J. R., et al (2014) menunjukkan bahwa Sebagian besar manajemen kunci (69\%) menilai risiko rusaknya reputasi perusahaan sebagai faktor penting yang menghalangi mereka untuk mengadopsi strategi penghindaran pajak yang agresif. Mengacu pada hasil penelitian ini menunjukkan bahwa perusahaan yang terbit di bursa dan perusahaan besar cenderung lebih peduli tentang konsekuensi reputasi yang merugikan akibat keputusan penghindaran pajak. Namun, sebaliknya perusahaan kecil justru cenderung lebih termotivasi dalam melakukan penghematan pajak untuk mengurangi beban yang dapat mengurangi keuntungan perusahaan. Sehingga dapat disimpulkan bahwa pemberian skema kompensasi manajemen memang dapat menyelesaikan konflik kepentingan seperti yang dikaji dalam teori agensi. Namun, terbukti bahwa kompensasi manajemen dapat mengendalikan perilaku oportunis manajemen untuk melakukan penghematan pajak atau justru mencegah pengambilan keputusan penghindaran pajak agresif yang dapat merusak reputasi perusahaan.

Selain itu, hasil temuan penelitian ini menunjukkan bahwa pentingnya komposisi dewan komisaris dengan aspek keahlian akuntansi maupun perpajakan yang memadai untuk dapat mendeteksi maupun mencegah adanya Tindakan oportunis dari pengambilan keputusan terkait penghindaran pajak perusahaan yang melewati batas hukum dan berisiko bagi masa depan perusahaan. Hasil ini konsisten dengan temuan dari penelitian Chen, M. C., et al (2020) yang juga menemukan hubungan negative antara kompensasi dan penghindaran pajak perusahaan. Dapat dikatakan bahwa kompetensi dan keahlian akuntansi maupun pajak yang dimiliki oleh dewan komisaris dapat mengurangi praktik penghindaran pajak yang relative berisiko bagi perusahaan (Jiang, F. et al., 2013). Dewan komisaris yang memiliki keahlian yang baik tentunya cenderung lebih konservatif dan mengutamakan kualitas laba yang lebih tinggi. Keahlian yang dimiliki oleh dewan komisaris dapat mengawasi dan mengarahkan keputusan manajemen yang menguntungkan namun tetap menjaga reputasi dan masa depan perusahaan.

\section{SIMPULAN}

Skema kompensasi manajemen dapat memainkan peran penting dalam membuat keputusan yang mendorong kinerja operasional perusahaan. Tidak dapat dipungkiri bahwa besarnya beban pajak yang ditanggung oleh perusahaan dapat mempengaruhi berbagai keputusan bisnis dan kinerja keuangan. Namun, adanya manfaat ekonomis dan risiko yang mungkin timbul dari praktik penghindaran pajak tentunya menjadi pertimbangan bagi perusahaan. Sebagian perusahaan mungkin cenderung untuk mendapatkan manfaat ekonomis dari penghematan pajak (Hanlon, M. et al., 2005; Minnick \& Noga, 2010), sedangkan sebagian lainnya justru lebih konservatif untuk menghindari risiko dari penghindaran pajak (Desai, M. \& D. Dharmapala., 2006; Zulma, G.W.M., 2016). Melalui skema kompensasi, pemilik dapat menyelaraskan kepentingannya dengan manajemen perushaaan. Kompensasi yang diberikan dapat menjadi motivasi manajemen untuk melakukan penghindaran pajak atau dapat juga membatasi tindakan oportunis manajemen untuk melakukan penghindaran pajak yang berisiko bagi perusahaan. Hal ini terbukti dari temuan penelitian yang menunjukkan adanya pengaruh non-linear antara kompensasi manajemen terhadap penghindaran pajak.

Selain itu, penelitian ini menemukan bahwa dewan komisaris dengan keahlian akuntansi dan pajak dapat berkontribusi pada kinerja keuangan perusahaan dengan memanfaatkan alternatif perencanaan pajak dengan lebih baik. Keahlian dewan komisaris dapat membuat fungsi pengawasannya menjadi lebih efektif. Keahlian akuntansi berkaitan erat dengan keputusan perpajakan sehingga perusahaan dengan proporsi dewan komisaris yang memiliki keahlian yang baik dapat mengambil keputusan yang lebih efektif terkait penghindaran pajak. Beberapa penelitian terdahulu seperti Jiang, F. et al (2013) dan Chen, M. C., et al (2020) menemukan bukti bahwa aspek keahlian yang dimiliki oleh dewan komisaris dapat mengurangi praktik penghindaran pajak yang relative berisiko bagi perusahaan. Dewan komisaris dengan keahlian akuntansi dan perpajakan yang baik cenderung lebih konservatif dan efektif dalam mengawasi keputusan manajemen terkait penghindaran pajak.

Hasil temuan ini dapat berkontribusi dalam pengembangan bidang perpajakan dan tatakelola perusahaan yang memberikan arah baru untuk melengkapi temuan penelitian sebelumnya khususnya terkait hubungan antara kompensasi manajemen dan penghindaran pajak perusahaan. Selain itu, hasil penelitian ini dapat menjadi masukan bagi regulator dalam mengawasai dan mengatur tatakelola perusahaan menjadi lebih baik khususnya terkait skema kompensasi dan kebutuhan keahlian pada komposisi dewan komisaris perusahaan. Adapun keterbatasan penelitian ini yang hanya menggunakan jenis data sekunder sehingga analisis yang dilakukan belum dapat menggali 
lebih dalam terkait penghindaran pajak yang terjadi secara praktis nya. Sehingga diharapkan penelitian selanjutnya dapat memilih alternatif metode seperti, eksperimen maupun mixed-method agar dapat menggali lebih dalam informasi terkait praktik penghindaran pajak perusahaan.

\section{DAFTAR PUSTAKA}

Armstrong, C. S., Blouin, J. L., Jagolinzer, A. D., \& Larcker, D. F. (2015). Corporate governance, incentives, and tax avoidance. Journal of Accounting and Economics, 60(1), 1-17.

Armstrong, C. S., Blouin, J. L., \& Larcker, D. F. (2012). The incentives for tax planning. Journal of accounting and economics, 53(1-2), 391-411.

Burchman, Seymour \& Blair Jones. (2006). Executive Compensastion as a Support For a Growth Strategy. World at Work Journal, 3 (2), pp: 88-93

Chen, M. C., Chang, C. W., \& Lee, M. C. (2020). The effect of chief financial officers' accounting expertise on corporate tax avoidance: the role of compensation design. Review of Quantitative Finance and Accounting, 54(1), 273-296.

Desai, Mihir A. and D. Dharmapala. (2006). Corporate Tax Avoidance and High-Powered Incentives. Journal of Financial Economics 79: 145-179.

Ge W, Matsumoto D, Zhang JL (2011) Do CFOs have style? An empirical investigation of the effect of individual cfos on accounting practices. Contemp Account Res 28:1141-1179. https ://doi.org/10.1 111/j.1911-3846.2011.01097.x

Graham, J. R., Hanlon, M., Shevlin, T., \& Shroff, N. (2014). Incentives for tax planning and avoidance: Evidence from the field. The Accounting Review, 89(3), 991-1023.

Hanlon, M., Mills, L. F., \& Slemrod, J. B. (2005). An empirical examination of corporate tax noncompliance. Ross School of Business Paper (1025).

Hoseini, M., Gerayli, M. S., \& Valiyan, H. (2019). Demographic characteristics of the board of directors' structure and tax avoidance. International Journal of Social Economics.

Jensen, M.C. and Murphy, K.J. (1990) Performance pay and top-management incentives. Journal of Political Economy 98(2): 225-264.

Jiang, F., Zhu, B., \& Huang, J. (2013). CEO's financial experience and earnings management. Journal of Multinational Financial Management, 23(3), 134145.

Low, A. (2009). Managerial risk-taking behavior and equity-based compensation. Journal of financial economics, 92(3), 470-490.

Minnick, K., \& Noga, T. (2010). Do corporate governance characteristics influence tax management?. Journal of corporate finance, 16(5), 703-718.
Rego, S. O., \& Wilson, R. (2009). Executive compensation, tax reporting aggressiveness, and future firm performance. Research Gate.

Scott, R.W. (2009). Financial Accounting Theory. New Jersey: Prentice-Hall, Inc.

Tang, T., \& Firth, M. (2011). Can book-tax differences capture earnings management and tax management? Empirical evidence from China. The International Journal of Accounting, 46(2), 175-204.

Vovchenko, N. G., Ivanova, O. B., Kostoglodova, E. D., Otrishko, M. O., \& Dzhu, O. S. (2016). Innovations and fighting global economic problems. Contemporary Economics, 10(4), 289298.

Yusuf, I.S. Dirjen Pajak angkat bicara soal kerugian Rp 68,7 triliun dari penghindaran pajak. Kontan.co.id. Diakses pada 23 November 2020. https://nasional.kontan.co.id/news/dirjen-pajakangkat-bicara-soal-kerugian-rp-687-triliun-daripenghindaran-pajak

Zulma, G. W. M. (2016). Family Ownership, Management Compensation, And Tax Avoidance: Evidence From Indonesia. The Indonesian Journal of Accounting Research, 19(1). 